\author{
Olegs N̦ikadimovs \\ $M B A$ \\ "HOTEL SCHOOL" Hotel Management College, Riga, Latvia \\ E-mail: mailto:olegs@hotelschool.lv \\ Tetiana Ivanchenko \\ "HOTEL SCHOOL" Hotel Management College, Riga, Latvia
}

\title{
Soft skills gap and improving business competitiveness by managing talent in the hospitality industry
}

\begin{abstract}
The purpose of this paper is to develop a deeper understanding of talent management strategies and practices in the hospitality industry context paying additional attention to soft skills gap. This study on talent management is limited and fragmented, that is why integrative literature review has been chosen as a method used to identify and analyse relevant studies, theoretical concepts in order to develop a deeper understanding and create a more comprehensive study of the strategies reviewed, and possibly to provide some solutions.

Results from the literature review showed that talent management has a positive and strong association with competitive advantage, performance and talent positioning (Anwar \& Nisar, 2014). New theoretical concepts and framework for talent management in the hospitality industry are beginning to develop, and it is a pathway for a hospitality company to reach its strategic goals and objectives. Competencies that have remained on the list of required skills include the soft skills of communication, customer focus, interpersonal skills and leadership (Johnson, Ghiselli, Shea, and Roberts, 2011). The performance of the company can be negatively impacted by skills gap due to unsatisfying levels of productivity and lacking quality (Bennett \& McGuinness, 2009).

The limitations of this study might be listed as having limited design due to a variety of constraints, that is why it can be viewed as fragmented, although this study adds to adds to the overall scope of literature on talent management, soft skills gap in the hospitality industry.

Practical implications can generally help the practitioners to place emphasis on the development of soft skills and implement better talent management strategies to ensure that a positive image of the organization is consistently presented.

Based on results, the future research should be conducted on the outputs and effects of these talent management concept and strategies, as well as how it can facilitate the soft skills gap closure on individual and organizational performance. Conducting an empirical research, both qualitative and quantitative, which includes observation or implementation of these practices may be useful to further build on the literature.
\end{abstract}

\section{Keywords}

talent management, hospitality industry, soft skills, strategic management

\section{Statement of the Problem}

Talent management and personnel performance management is one of the management functions and the most important factor in achieving business success and efficacy, especially in the hospitality industry, which is the service industry relying greatly on employees' performance. With good planning and implementation, the talent management systematic approach becomes an effective way to achieve high business results and greater competitiveness in todays overcrowded 
and volatile markets.

Talent management is viewed upon as one of the key human resource aspects and as a great challenge by many leading international companies such as IBM and Shell (Paauwe, 2009). Studies published in the popular and practitioner journals, as well as consulting companies, pay a great attention to talent management concept progression and how to win the 'battle and war for talent' (Iles, Preece, \& Chuai, 2010; Vaiman, Scullion, \& Collings, 2012). According to the results of the Global Human Capital Trends - 2017 study, the transformation of the performance management model has become one of the key priorities for managers (Deloitte, 2017). Management wants to see an organization's easyto-use system that can efficiently manage employee productivity in dynamically changing environments with a high level of uncertainty.

Hospitality companies should always assess the knowledge, skills, and abilities (KSAs) of their candidates when selecting the right talent for their companies. There are very few tested and reliable methods available to assess soft skills of candidates. The possibility may exist that some hospitality companies may not be concerned with the hard skills and abilities of their candidates as they hope to develop their talent after recruiting them according to the company standards, but the softs skills are already expected to be there to be successful within their organization. That is how the soft skills gap might be formed.

Definitions of the terms hard skills and soft skills have been coined and suggested by many authors along the way (for instance: Clark, 1993; Wellington, 2005; and Rainsbury, Hodges, Burchell, \& Lay, 2002). Soft skills are defined as the interpersonal, human, people, or behavioural skills needed to apply technical skills and knowledge in the workplace (Kantrowitz, 2005; Rainsbury, Hodges, Burchell, \& Lay, 2002). A study determined to find out the competencies required to the hospitality and tourism graduates concluded that communication skills and the ability to manage and motivate employees were ranked as two of the most important soft skills (Mayo \& Thomas-Haysbert, 2005). In the essential category of the competencies need to the hospitality and tourism graduates, majority of them were related to soft skills needed to develop good working relationships with customers and employees.

The purpose of this paper is to develop a deeper understanding of talent management strategies and practices in the hospitality industry context paying additional attention to soft skills gap and possibly provide some recommendations. In this study, the topic of human resource management, and specifically talent management, will be reviewed. Hotel organizations are working hard to achieve a competitive advantage over others, but there is still a big gap, the real situation is different from the desired one.

The relevance of this topic is high, since talent management is the cornerstone of the strategic management and competitiveness of any organization, and soft skill gap is the problem that should be studied more extensively, especially in the hospitality industry context. From all of the above, the researchers formulate an agenda for future talent management research, possibly highlighting new directions for the future empirical research in a wide range of the hospitality industry organizations with the purpose of overall progress and advancing academic knowledge in talent management field within the hospitality industry.

\section{Literature Review}

According to Betchoo, talent management is a set of tools and strategies so that a company can attract, efficiently use and improve the quality of its personnel, which makes it possible to make a significant contribution to the development of the company. The term talent management includes activities aimed toward involving staff within the innovation techniques, making creative incentives, and developing potential of staff. (Betchoo, 2017). "The practices like attraction, recruitment and engagement plays an important role while managing talent" - according to Anwar and Nisar,; the authors have conducted a study in the banking sector of Pakistan and described the need and benefits of talent management, described key methods and came to the following conclusions: "Talent management plays an effective role and its integration at all levels of the banks, improves performances. Banks should give proper attention in attracting new employee, recruiting current employees, and engaging them for the betterment of employees and companies it-self. Talent management is a relatively new concept for effective management of key employees that should be made part of company's strategy. Organizations in developing countries like Pakistan should address this issue. Being a relatively less researched area, it has a wide scope and opportunity for new researcher's in Pakistan. Study results also shows that talent management also has positive and strong association with competitive advantage, performance, and talent position within the banking sector." (Anwar \& Nisar, 2014). Baqutayan thinks that talent management is of importance to employees and should be of importance to the company as well because it can lead to a competitive advantage to all employees. Therefore, they conclude that talented can be anyone, just talents need to want to develop. The meaning of talent management is to hire suitable candidates for suitable positions and help them develop their skills (Baqutayan, 2014). The analysis 
by recognizes that the hospitality industry in terms of human resources is very often faced with problems. Making decisions on these issues affects the quality of guest service and the competitiveness of the organization in the hospitality industry. But also, the hospitality industry has the advantage that, thanks to trained students, a large percentage is ready to work in hospitality companies. Hospitality companies can improve their performance by participating in research efforts, improving coordination with educational institutions, and building relationships with students. The authors believe that organizational effectiveness is no longer measured only by profit, but now they pay attention to what talents a team of a company has, what skills employees have to become a key contribution to a highly competitive environment (Nzonzo \& Chipfuva, 2013). "Talent is a strategic issue, and a human capital strategy is an intrinsic part of any business strategy. This means understanding the value of talent, and recognizing the critical components of business strategy that require us to think through the talent and organizational implications and options" (Cheese, Thomas \& Craig, 2008). According to Chartered Institute of Personnel and Development "Talent consists of those individuals who can make a difference to organizational performance either through their immediate contribution or, in the longer-term, by demonstrating the highest levels of potential. Talent management is the systematic attraction, identification, development, engagement, retention and deployment of those individuals who are of particular value to an organization, either in view of their 'high potential' for the future or because they are fulfilling business/operation-critical roles" (CIPD, 2012). "In groups, talent can refer to a pool of employees who are exceptional in their knowledge, skills, and abilities either in a specific technical area (such as financial asset management), a specific competency (such as innovative thinking), or a more general area (such as general management or leadership potential talent)" (Silzer \& Church 2009:380). "In the literature, retaining employees mean an effort to create an environment which keep engaged of employees and encourage employees to remain with organizations for a maximum period of time. For more detailed and recent definition for the concept of employees retention, it is known as the process in which employees is encourage to stay with organizations for a long period of time despite more attractive salaries elsewhere" (Nema \& Nougriaya, 2015). "The term 'talent' has existed in multiple languages for thousands of years at least - as demonstrated by the Parable of the Talents - but has also been defined differently over the centuries. Before the $14^{\text {th }}$ century, 'talent' as a noun had a denotative meaning. It referred to a precisely defined denomination of silver, and so was simultaneously (and without contradiction) a denomination of weight and a unit of currency. This sense of 'talent', as in 'one talent of silver', is in the early interpretation, compared with later interpretation of the Parable of the Talents, primarily the denotative meaning" (Tansley, 2011). Maxwell and MacLean points out that talent management is adopted throughout the industry as a distinct approach to managing people so as to promote positive perceptions of the industry, both the service provider and the employer, in order to show that company employees are highly valued, as well as improve people's opinions about work and careers in the hospitality industry, so talented employees will increasingly choose this industry. Each organization practices TM techniques, choosing those that correspond to their business introduction, employees, guests, this means that each company decides who they think talented employees are (Maxwell, MacLean, 2008). Rathore and Rathore discovered talent management practices in luxury and low budget hotels. The authors of the study argue that talent management is often practiced in the hospitality industry. Their article talks about the differences in talent management depending on the types of hotels and their class. They advised hotels to conduct selfassessments to get employees' perspective, seek the opinion and experience of others, give goals to employees, help the stuff to improve and succeed with development plans and implement pay to reward good performance (Rathore \& Rathore, 2015). It is also worth discussing soft skills. Dean and East believe that some workers lack soft skills. The soft skills deficit includes oral communication, problem solving, low self-confidence, and interpersonal skills. The lack of soft skills directly affects the efficiency of the company, the involvement of employees and their safety. Companies need to implement soft skills training programs to eliminate lack of skills. Failure to organize this has serious consequences and negative business outcomes in this highly competitive global work environment (Dean \& East, 2019). Singh considers that students do not have realistic expectations of their levels of workforce preparedness. Employers expect too high and too large skills in the field of critical thinking, creative approach, application of knowledge and skills in the real world. This is because every employer wants to provide himself with the most competent employees. Lack of training made participants feel less fit for their work. Also, employees with good soft skills may not use their full potential if there are no simple organizational procedures, such as formal orientation (Singh, 2018). Oxenbridge and Evesson conducted a research and found out how young people start their work in Australia. A large percentage of young people who enter the labor 
market know that employers require soft skills from them. They emphasize skills such as selfmanagement and communication skills, confidence, and showing initiative. The authors also emphasized that companies want young employees to come fully trained and possessing soft skills. The presence of training programs at work is necessary for young people to improve their soft skills, as this is the most effective way. It is also noted that young employees are much better and more effective in the presence of a supervisor, mentor and support programs (Oxenbridge \& Evesson, 2012). The study of Wilks and Hemsworth shows what qualities hotel managers consider necessary for graduates in the hospitality industry. Most managers chose: being able to work in a team, leadership, problem solving, sensitivity to customer needs, empathy, to act calmly. Least of all gained such skills as: environment protection practices, IT systems management, ability to conduct a market study (Wilks \& Hemsworth, 2011). Some researchers also conducted a research in the field of talent management and predicted future trends in this area. They believe that platforms such as Taleo or LinkedIn will be the most affordable and convenient way to find talent (Ariss, Cascio \& Paauwe, 2013).

Thus, it is possible to say that these issues are relevant all over the world now. Hospitality industry needs the well prepared and highly motivated graduates who are willing to work because the lack of soft skills and students do not have realistic expectations of their levels of workforce preparedness. Therefore, the attraction and training, the development of their soft skills is especially important to improving business competitiveness.

"Human resource management (HRM) is the process of employing people, training them, compensating them, developing policies relating to them, and developing strategies to retain them. As a field, HRM has undergone many changes over the last

TABLE 1 Six Talent Management dimensions “Talent Management: An Overview" (Rao, 2009)
Talent Management Dimensions

Develop Strategy

Attract and retain

Motivate and develop

Deploy and manage

Connect and enable

Transform and sustain twenty years, giving it an even more important role in today's organizations. In the past, HRM meant processing payroll, sending birthday gifts to employees, arranging company outings, and making sure forms were filled out correctly - in other words, more of an administrative role rather than a strategic role crucial to the success of the organization." (University of Minnesota, 2016) To effectively manage the organization, there is such a tool as the human resource management. In each company, people are the most important resources that provide work, and the hospitality industry pays special attention to this. People create new products, use resources, control quality. The most important thing is that people can constantly improve and develop, if desired. The student believes that personnel management directly affects the value of the company. For the development of talents in staff, improving their skills, there is such a subsection in HR as talent management. This is important since the human component of the hospitality organization is considered as one of the most important resources for its successful functioning and development, a factor in its effectiveness and growth, and a means of achieving strategic goals.

The authors have analysed all the opinions of definition concepts, and agree with each statement in own way, but more precise statement is "Talent management is the science of using strategic human resource planning to improve business value and to make it possible for companies and organizations to reach their goals". (Tyskbo, 2019) New and highly skilled talents plays a crucial role not only in Hospitality Industry but also in any kind of companies to achieve goals and to make a sustain business. The essential point of all that is term strategy, because if look from long term perspectives what is extremely important for business and for future company prosperity, maintain and develop new talents will be a good strategy to success.

Establishing the optimum long-term strategy for attracting, developing, connecting and deploying the workforce

Sourcing, recruiting and holding onto the appropriate skills and capitalize, according to business needs

Verifying that people's capabilities are understood and developed to match business requirements, while also meeting people's needs for motivation, development and job satisfaction

Providing effective resources deployment, scheduling and work management match skills and experience with organizational needs

Identifying individuals with relevant skills, collaborating and sharing knowledge and working effectively in virtual settings

Achieving clear measurable and sustainable change within the organization, while maintaining day to day continuity of operations 
A shown in a Table 1, talent management has 6 very important dimensions that has a logical framework without which the effective management of new talent would not have been possible. It is worth noting that it is very difficult to keep young talent in companies because it is influenced by many different factors and therefore the authors consider that the key point is the retention of talent, as well as the motivation and its development. Moreover, deploy and manage could be very hard task for employees as in our planet exist different cultures and human beings with their own opinions and views.

The essence of personnel management is to establish organizational, economic, sociopsychological and legal relations of the subject and the object of management. These relations are based on the principles, methods and forms of influence on the interests, behaviour and activities of workers in order to maximize the use of their knowledge and skills (Daley, 2012).

Dubreuil et al. (2011), in their article "Building on the strengths of employees to improve functioning at work", specify that to increase staff performance, managers generally have to evaluate and identify their weaknesses, and then improve them. A meta-analysis of measuring employee engagement at work demonstrates this (Q12 Gallup, 2009): the results indicate that the management style has a direct impact on staff engagement depending on whether the manager ignores the contribution of his employees ( $2 \%$ engagement), the manager pays attention only to the weaknesses of his employees ( $45 \%$ engagement) or the manager supports employees and makes efforts for the development of their strengths (61\% engagement) Personnel engagement positively affects the following business results: customer ratings, profitability, productivity, turnover (for high-turnover and low-turnover organizations), safety incidents, shrinkage (theft),absenteeism, patient safety incidents and quality (defects), according to Gallup (2013). Thus, personnel commitment is determined by active and enthusiastic participation at work (Khan et al., 2011), which is crucial for high personnel performance at work.

According to Zhang (2012), typically, employee performance management system comprises of three phases, shown on Figure 1.

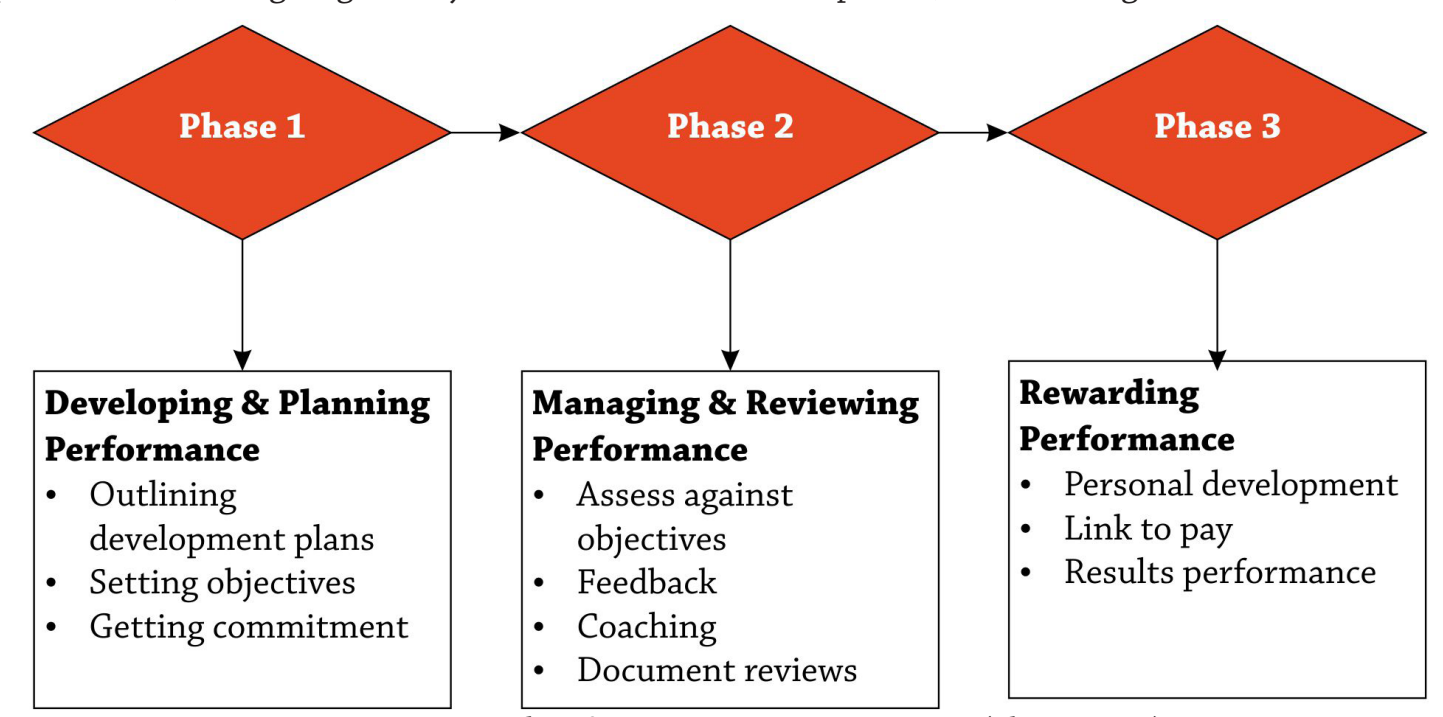

Figure 1 Personnel performance management system (Zhang, 2012)

Thus, the first phase of personnel performance management system is development of personnel and planning its performance with clear objectives and reading commitment to these objectives. The second phase so concerned with management or personnel performance and regular reviews and assessments, based on feedback, coaching and document reviews. Finally, the third phase is rewarding performance, which is designed personally for each employee and is based on their results. This could also be related to personal development and linked to the salary that is based on performance.

Doing what we love and using our strengths by choice is very satisfying (Harzer \& Ruch, 2012;
Linley et al., 2010; Clifton \& Buckingham, 2001). However, at work, performing certain roles and responsibilities, in exchange for a salary, employees don't do only what they would like to do, and it is not always possible to achieve this at work. However, having the choice to do so is very motivating, with autonomy being a major factor in personnel motivation (Pink, 2011). So that when the work becomes interesting and motivating, employees find a meaning in it and are more committed to the company. This leads to higher performance and a sense of well-being that is more important than salary.

Every employer wishes for competent, motivated, happier, less physically and 
psychologically distressed staff in their organizations. The advent of positive psychology could prove to be a powerful approach in human resource management.

According to P. Dubreuil, J. Forest and F. Courcy (2014) in the strengths of people have three main components: the natural aspect (authenticity), high performance (success, quick learning, optimal functioning) and energy (vitality, enthusiasm).

Traditional performance evaluation systems include:

- Annual / semi-annual meetings with discussion of the employee's work and setting goals and objectives for the year ahead.

- A rating system for employees based on ratings for one or another project put up during the year.

- Various assessment methods, including interviewing team members (e.g. 360 rating).

Each of these points has recently been increasingly criticized. Thus, the results of many studies indicate the inefficiency of the annual assessment of employees with the subsequent setting of goals and objectives for the year ahead.

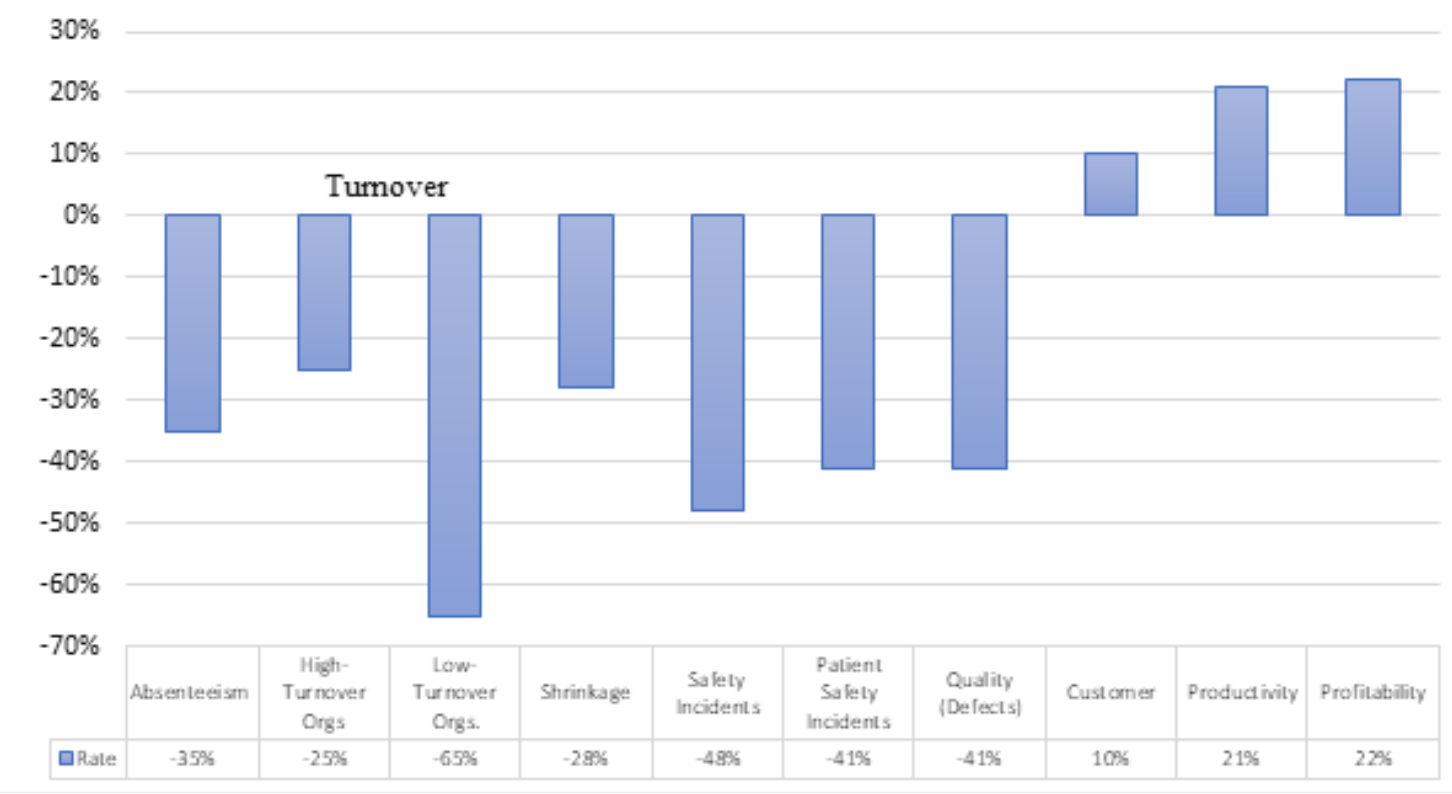

Figure 2 Relationship between staff engagement and business results (Gallup, 2013

As seen above (Figure 2), according to Gallup statistical data, employee engagement can affect key business outcomes. Work units in the top quartile in employee engagement outperform bottom-quartile units by $10 \%$ on customer ratings, $21 \%$ in productivity, and $22 \%$ in profitability. Work units in the top quartile also saw significantly lower absenteeism (37\%), turnover (25\% in highturnover organizations, $65 \%$ in low-turnover organizations), and shrinkage (28\%) and fewer safety incidents (48\%), patient safety incidents (41\%), and quality detects (41\%) (Gallup, 2013).

A survey conducted by Globoforce showed that of the 708 employees surveyed by various American companies, more than half do not consider such a rating system to be effective and motivating, and more than $60 \%$ do not agree with the results of annual assessments. At the same time, $88 \%$ of employees who agree with the results of the survey said that they love their work and are happy with the place they occupy in the company. Among those who disagree, the percentage of employees satisfied with the work was $30 \%$ less (Theoretical and applied science, 2017). Such statistics show the impact of employee performance assessment methods on their company loyalty.

As a result, today many companies are reviewing their existing performance management systems. $89 \%$ of the companies participating in Deloitte's study of current HR trends have already upgraded their systems or have planned an update for the next 18 months (Deloitte, 2015).

Talent management is needed in order to develop the employee's abilities, improve his weaknesses. This is especially important because the student believes that modern youth does not have sufficient skills at the start of work. This is especially true for soft skills. Young people are strong in digital technologies, in knowledge of the language, but lacking a sense of responsibility, the ability to perceive criticism, time management, problem solving, service skills and sometimes manners. M. Joshi describes soft skills in the following way: "the personal character traits or qualities each of us has. They make us who we are, generally encompassing our attitudes, habits and 
how we interact with other people. They refer to abilities that make people better employees and open doors for many opportunities that are not directly related to the subject matter of their jobs. In other words, soft skills refer to a person's ability to relate to others, to get him / her and others organized, to communicate in written, spoken or other forms." (Joshi, 2017). Also, he concludes that soft skills help everyone solve problems, think, make decisions, communicate, build healthy relationships, become a leader and competently build a team, also manage time efficiently, cope with stress and stress without harming mental health.

B. Tulgan also believes today's young people can offer a lot, for example, new technical knowledge, innovative ideas, they are perspective and energetic, but at the same time too much are restrained. They strain the older generations with their behaviour and manners due to weak soft skills. He says that young workers do not know how to think critically, study, communicate without their phones. Their work habits are terrible, they have no sense of responsibility and self-sacrifice for the sake of a common goal, in this case, the effective work of hospitality company. "There is a growing gap between the expectations of employers and the reality of how today's new young talent is showing up in the workplace." (Tulgan, 2015)

\section{Soft Skills Gap}

\subsection{SOFT SKILLS}

Interpersonal Skills - are defined as the social and interpersonal qualities necessary to promote and interact with other people (Azim et al., 2010, Gibb, 2014). Interpersonal skills are often the main aspect in literature with cognitive skills focusing primarily on cognitive domain and measure by standardized skills (Franz 2014). Wheaton, 1990 argues that manager's success depends on being able to manage behaviour with others and also to build his own behaviour depending on the situation. The term interpersonal skills are interchangeably used with social skill, human skills, and face-to-face skills.

Communication Skills: can be defined as the transmitting process of information from individual-to-individual (Keyton, 2008). Communication study is important for both organization and employees because each activity needs one or other form of communication. So, communication is the factor that affects the effectiveness of individual and organization (Brun \& Cooper, 2016).

\subsection{HARD SKILL}

Technical Skills: The ability to use special skill or expertise to perform a particular job is technical skill Green, 2011 defines technical skills as the ability of one unit of labour effort to convert input into output and (Green, 2011) also states that minimum requirement of technical skill is needed to solve complex problem. With this importance of technical skills, management should support improving the technical skills of employees (Kirkley \& Dupaul, 1989). But alone technical skill is not sufficient to improve performance of employees (Nicole, Vaughan, Zabihullah, \& Mei, 2016).

Problem Solving Skills: Enhancing problem solving skills are the best practice of good organization (Bereiter \& Scardamalia, 1993) The organization relies on this skill of employees to solve complex problems and to face uncertain circumstances (Schon, 1987). Many organizations are enhancing problem solving skills of employees through development programs (Lohman \& Finkelstein, 2000). Although the technology has reduced the problem-solving capabilities of employees, there has emerged new forms of problems solving abilities (Brand-Gruwel \& Stadtler, 2011).

Decision Making Skills: The term problem solving and decision making is often used in the workplace interchangeably, but is not the same. As the term suggest, problem solving begins with problem identification, whereas decision making skills are necessary for solving problems. The ability of employees to take decision is influenced not only by knowledge and experience but also the structural empowerment prevailing in the organization (Wu, Yang, Liu, \& Ye, 2016).

\subsection{SOFT SKILLS GAP}

In the literature review over the past 25 years it was determined that there were changes in competencies required for managers in the U.S. hospitality industry. Competencies that have remained on the list of required skills include the soft skills of communication, customer focus, interpersonal skills, and leadership (Johnson, Ghiselli, Shea, and Roberts, 2011), with leadership, a soft skill, was ranked the highest in the 2009 survey.

In 1994, food and beverage management competencies were reported by Okeiyi, Finley, and Postel, identifying soft skills as essential competencies for food and beverage managers. A study to determine competencies needed by hospitality and tourism graduates found that communication skills and the ability to manage and motivate subordinates were ranked as two of the most important skills (Mayo \& Thomas-Haysbert, 2005). In the essential category of the competencies all of them were related to soft skills needed to develop good working relationships with customers and employees. 
The American society for training and Development (ASTD) defines skill gap as gap between the current capability of organization and skills it needs to achieve its goal. Therefore, it can be referred to as perceived mismatch between employer's skills need and the available employees' skills. Some people often refer to the skill gap as a compensation gap where employers are not willing to pay sufficiently to bring in the skill required. Others call it a training gap where employers do not provide necessary training or the gap in the education and the employers need (EMSI, 2013).

The skill gap in the organization can be defined as the gap which does not allow to grow or to remain competitive as it is unable to find employees with right knowledge to fit into the critical job. Therefore, the performance of the company will be hampered by skill gap due to low productivity and lack of quality (Bennett \& McGuinness, 2009).

The academic literature review suggests the following - academic system imperfections that fails to train graduates with basic soft skills and technology skill (Salas, Shuffler, Thayer, Bedwell, \& Lazzara, 2015, Livingstone, 2018, Makransky et al., 2016, Berger \& Frey, 2016, Genlott \& Grönlund, 2016). New employees are failing to socialize to working environment (Song, Chon, Ding, \& Gu, 2015) and the fast-changing environment. With the rise in the labour competition, hospitality organizations are increasing their scrutiny of employee's skills they needed because of skills required for the working environment.

Skill gap analysis is needed to evaluate employee skills. During the assessment, the level of knowledge and skills of a person is tested for successful and effective work. After the analysis, the human resources management department draws up a plan on how to close these gaps (EMSI, 2013) For this, the company must determine its business goals, so it will be easier to understand what skills an employee of the organization should possess. Then need to work in a narrower direction and draw up the necessary skills, knowledge, and qualities for a specific vacancy. A training plan is already being drawn up for this. It can be made up of a human resources management department or special organizations that specialize in training people (Armstrong \& Taylor, 2014). IBM offers strategies to close skills gaps in the organization. The authors suggest taking advantage of outsourcing, moving talents between departments in the company, attracting talents from abroad and introducing educational programs for staff development. (IBM, 2019) A talented employee is a combination of labour potential and characteristics. If company develops employees, each of them will contribute to the achievement of goals, thanks to their effective work. If the company does not have talented employees, it may begin to inappropriately switch to other things, such as marketing. But investing in it is dangerous without talented employees, since not a single advertisement will save the organization if it cannot provide quality service thanks to trained employees.

The first thing a young worker must learn is self-evaluation. Many people are not able to critically evaluate themselves. And when mistakes are constructively pointed out to them, they are offended or simply do not pay attention, thinking that the person is wrong. As soon as a person learns to evaluate himself - he will begin to learn and improve. Firstly, management can use tests that describe personality types, interests, values, and communication style. After that, move on to more specific tools. Tulgan offers tools like MyersBriggs Type Indicator, which divides people into 16 personality types based on how they make decisions, how they solve problems, and whether they solve them at all. Another tool called "Enneagram" divides people into 9 categories and makes it clear that the person is best motivated. The most important thing is to develop a habit for young people to regularly evaluate themselves, and for greater motivation to record progress, use scorekeeping so that they can evaluate their successes (Tulgan, 2015).

Often people point to external factors and other people to justify their mistakes or shortcomings. Workers need to be taught to focus on factors that are under their control. A great idea is to hold meetings with employees and brainstorm, ask for their opinions on what personal responsibility is all about, ask for examples from work, all of the factors that get in the way of their ability to do job and make it harder for they to perform at the highest level. "When it comes to teaching personal responsibility, the key is keeping the focus on factors within the control of the individual-teaching people to ask themselves every step of the way: What is within my control right now? Where will I focus my attention and energy? What are my options? What is the plan? What are my next steps? What are my next thoughts, words, and actions?" (Tulgan, 2015). Thus, reliability develops, a person's willingness to fulfil the agreements and his duties honestly and diligently, understanding that mistakes must be paid. Willingness, with a reasonable need, to take on difficult moments of life. A developed sense of responsibility is a sign of adulthood.

Positive attitude is one of the components of success and personal growth. It can facilitate someone to believe themselves. A positive attitude helps to look for perspectives, opportunities, direct energy and get the desired results, this is a big component of success and personal growth. Negative emotions constrict thinking and limit thoughts. The power of positive thinking is 
comprehensively examined in the famous book "Think and Grow Rich" by American writer Napoleon Hill. The authors meticulously collected many examples when people achieved success solely because of their belief in success. (Hill, 1937) To think positively, a person should work on that position and do what he is well versed in. Also, the company must ensure a balance between work and free time, so that a person has time to engage in their hobbies, which make them happy. It is necessary to avoid toxic relationships. It is also important for young employees to learn how to leave their personal problems at home and not transfer them to the workplace. Also, important this is that "research shows that if you make an effort to display positive words, tones, and gestures on the outside, it has a positive effect on your internal brain chemistry and it actually makes you feel better on the inside." (Tulgan, 2015).

Teamwork is the activity of a group of people focused on solving a specific problem. To improve teamwork, it is necessary to introduce employees to each other to reduce the formal distance. It is also possible to arrange team sports games that involve every member of the team, the sport also helps in the fight against stress. Or management can organize a joint trip, a bike ride to get to know your colleagues better. More expensive but no less useful are seminars, lectures, educational events. It is also possible to celebrate the achievement of any goals of the company, to arrange a mini celebration. Someone is given these skills by nature; others must do serious work on themselves. But nothing is impossible and, if desired, it is possible to achieve excellent results. The employer is required to understand and desire to train young employees by investing in the future of their company, and young people should realize that the development of these skills is useful primarily for themselves.

\section{Results}

In current global economic conditions and global Covid-19 pandemic that have affected all sectors and especially tourism and hospitality sector, many hospitality companies have felt the pressure to consolidate the expenses and to improve their strategic competitiveness. These are the perfect conditions to execute a better talent management system as a means of optimizing the performance of each employee and organization altogether, as well as to pay additional attention to soft skill gaps that are. The high level of importance and interest in the strategies of talent management in the hospitality industry over the past decade, it is somewhat paradoxical that it remains relatively understudied and lacking in the theoretical support. New theoretical concepts and framework for talent management in the hospitality industry beginning to develop, where talent management is not the end result in itself or is about a creation of a career development plan for the employees, but is a pathway for a hospitality company to reach its strategic goals and objectives.

This study highlights certain aspects and perspectives of talent management. Literature review predominantly explained the concepts and of talent management for the hospitality organizations and the soft skills gap phenomenon. The reviewed concepts may connect industries' practitioners and academics in talent management disciplines, because this study has assessed some of the practices with the academic literature.

According to a 2016 Wonderlic study, 93 percent of employers believe that soft skills are especially important when deciding whether to hire a candidate. (Wonderlic, 2016) In the hospitality industry, soft skills are the most sought-after skills that will enable organizations to gain competitive advantage. Developing and retaining already existing talents in a team will be much more profitable than constantly looking for new the candidates. A training plan is already being drawn up for this. It can be made up of a human resources management department or special organizations that specialize in training people (Armstrong \& Taylor, 2014). There are six talent management dimensions (Rao, 2009), that has a logical framework without which the effective management of new talent would not have been possible. The other solution that crucial is for high personnel performance at work is personnel performance management system, that consists of three separate phases (Zhang, 2012). According to P. Dubreuil, J. Forest and F. Courcy (2014) in the strengths of people have three main components: the natural aspect (authenticity), high performance (success, quick learning, optimal functioning) and energy (vitality, enthusiasm); and performance evaluation systems should include all of these components.

The soft skills help everyone solve problems, think, make decisions, communicate, build healthy relationships, become a leader and competently build a team, also manage time efficiently, cope with stress and stress without harming mental health. (Joshi, 2017). There is a growing gap between the expectations of employers and the reality of how today's new young talent is showing up in the workplace, that is called skill gap (Tulgan, 2015). After reviewing the most important skills in the hospitality industry, the researchers have come to a conclusion that soft skills are of the crucial importance. Competencies that have remained on the list of required skills include the soft skills of communication, customer focus, interpersonal skills, and leadership (Johnson, Ghiselli, Shea, and Roberts, 2011), with leadership, a soft skill, was ranked the highest in the 2009 survey. The 
American society for training and Development (ASTD) defines skill gap as gap between the current capability of organization and skills it needs to achieve its goal (EMSI, 2013), the performance of the company will be hampered by skill gap due to low productivity and lack of quality (Bennett \& McGuinness, 2009). Thus, the researchers have concluded that to achieve the higher competitiveness, better performance and strategic advantage, hospitality businesses need to pay attention to soft skills gap and to find the possible solutions to close it. The first step to do is to undertake the skill gap analysis to evaluate employee skills, after the analysis, the human resources management department draws up a plan on how to close these gaps (EMSI, 2013).

\section{Recommendations}

Due to the fragmented nature of this study, only limited recommendations can be given by the authors, some of the perspectives how to change the situation and utilise better solutions are listed below.

According to Zhang (2012), typically, employee performance management system comprises of three phases, that are reviewed in the study, so a structured personnel assessment system can be created and implemented - based on this system the company also can decide on the bonuses, career opportunities, personnel development and training needs of the employees. The system could include - job knowledge tests; structured interviews; situational tests (experiments of the customer interactions); goal setting and following goal achievement for employees. The frequency of the employee performance assessment can be annual / semi-annual meetings with discussion of the employee's performance and setting goals and objectives for the year ahead (Dubreuil et al., 2014).

Another approach could utilise the six talent management dimensions, that includes the following stages - talent development strategy creation; attracting and retaining talent; motivating and developing talent; deploying and managing talent; connecting and enabling talent and, finally, transforming and sustaining talent with the organization (Rao, 2009). This created logical framework could help to effectively manage the talent with day to day continuity of operations. Such approach can help to establish organizational, economic, socio-psychological and legal relations of the subject and the object of management. These relations are based on the principles, methods and forms of influence on the interests, behaviour and activities of workers in order to maximize the use of their knowledge and skills (Daley, 2012).

Soft skills gap might be another challenge that hospitality organizations might face on their way to improving the business competitiveness. Competencies that have remained on the list of required skills include the soft skills of communication, customer focus, interpersonal skills, and leadership (Johnson, Ghiselli, Shea, and Roberts, 2011), with leadership, a soft skill, was ranked the highest in the 2009 survey. To close soft skills gap, firstly, management should perform aptitude tests and skill gap analysis needed to evaluate employee skill levels. After the analysis, management should develop a structured plan or strategy on how to close these gaps (EMSI, 2013) For this, the company must determine its business goals, so it will be easier to understand what skills an employee of the organization should possess. Structured plan should include necessary knowledge, skills and abilities for specific employees with a training plan is already being drawn up for this. It can be made up of a human resources management department or special organizations that specialize in training people (Armstrong \& Taylor, 2014). Assessment criteria and timing frequency of assessment should be established, once again it can be can be annual / semi-annual meetings with aptitude testing and discussion of the employee's performance and setting goals and objectives for the year ahead (Dubreuil et al., 2014). To improve performance, management needs to understand the motivation of the employees. Based on the findings, it can be concluded how to encourage the employees to improve their skills; to raise the motivation and interest of employees, it is necessary to notice and recognize their efforts (Tulgan, 2015). Employees need to instil a learning culture and be a part of solution.

\section{Implications and Future Research}

The limitations of this study might be listed as having limited design due to a variety of constraints, that is why it can be viewed as fragmented, although this study adds to the overall scope of literature on talent management, soft skills gap in the hospitality industry. Practical implications can generally help the practitioners to place emphasis on the development of soft skills and implement better talent management strategies to ensure that a positive image of the organization is consistently presented. Talent management can promote strengths of the talent - the natural aspect, high performance and energy, it also can influence employees' emotional labour, increasing the quality during the guest encounters.

Based on results, the future research should be conducted on the outputs and effects of these talent management concept and strategies, as well as how it can facilitate the soft skills gap closure on individual and organizational performance. Conducting an empirical research, both qualitative and quantitative, which includes observation or implementation of these practices may be useful to further build on the literature. 


\section{References}

[1] Anwar A, Nisar Q A 2014 Talent Management: Strategic Priority of Organizations International Journal of Innovation and Applied Studies $\mathbf{9}$ (3) 1148-54

[2] Ariss A A, Cascio W F, Paauwe J 2013 Talent management: Current theories and future research directions Journal of World Business 49 173-9

[3] Armstrong M, Taylor S 2014 Armstrong's Handbook of Human Resource Management Practice 13th Edition. Kogan Page, London, UK

[4] Baqutayan S M S 2014 Is Talent Management Important? An Overview of Talent Management and the Way to Optimize Employee Performance Mediterranean Journal of Social Sciences 5(23) 2290-5

[5] Bereiter C, Scardamalia M 1993 Surpassing ourselves: An inquiry into the nature and implications of expertise Teachers College Record

[6] Berger T, Frey C B 2016 Digitalization, Jobs, and Convergence in Europe: Strategies for Closing the Skills Gap. Oxford - Prepared for the European Commission DG Internal Market, Industry, Entrepreneurship and SMEs DOI: https://doi.org/10.1177/0002764217701217

[7] Betchoo N K 2017 People and Talent Management National Library of Mauritius

[8] Brun J P, Cooper C 2016 Missing pieces: 7 Ways to improve employee well-being and organizational effectiveness DOI: https://doi.org/10.1057/9780230233546.

[9] Buckingham M, Clifton D O 2001 Now, discover your strengths Simon and Schuster

[10] Cheese P, Thomas P J, Craig E 2008 Strategies for Globalization, Talent Management and High Performance The Talent Powered Organization, London and Philadelphia 7-46, 88-97

[11] CIPD 2012 Organisation development (online). Factsheet. London: Chartered Institute of Personnel and Development E-source: https://www.cipd.co.uk/knowledge/strategy/organisationaldevelopment/factsheet (Accessed 27 May 2020).

[12] Clark M 1993 Communications and social skills: Perceptions of hospitality man-agers Employee Relations 15(2) 51-60

[13] Daley D M 2012 Strategic human resources management Public Personnel Management 120-5

[14] Dean S A, East J I 2019 Soft Skills Needed for the 21st-Century Workforce International Journal of Applied Management and Technology 18(1) 17-32

[15] Deloitte 2015 Global Human Capital Trends 2015: Leading in the new world of work E-source: https:// www2.deloitte.com/au/en/pages/human-capital/articles/global-human-capital-trends-2015leading-new-world-work.html Accessed: 25 March 2020

[16] Deloitte 2017 Upravlenie effektivnostju personala: kak eto delatj praviljno? E-source: https:// www2.deloitte.com/content/dam/Deloitte/ru/Documents/human-capital/russian/upravlenieehffektivnostyu-personala.pdf Accessed: 25 March 2020 (In Russian)

[17] Dubreuil P, Forest J, Courcy F 2014 From strengths use to work performance: The role of harmonious passion, subjective vitality, and concentration The Journal of Positive Psychology 9(4) 335-49

[18] EMSI (Economic Modelling Specialist international) 2013 New Skills at Work, JP Morgan CHASE and CO

[19] Franz N 2014 Measuring and Articulating the Value of Community Engagement: Lessons Learned from 100 Years of Cooperative extension Work Journal of Higher Education Outreach

[20] Gallup 2009 Driving Engagement by Focusing on Strengths E-source: https://news.gallup.com/ businessjournal/124214/driving-engagement-focusing-strengths.aspx Accessed: 25 March 2020

[21] Gallup 2013 How Employee Engagement Drives Growth E-source: https://www.gallup.com/ workplace/236927/employee-engagement-drives-growth.aspx Accessed: 25 March 2020

[22] Genlott A A, Grönlund A 2016 Closing the gaps - Improving literacy and mathematics by ict-enhanced collaboration Computers and Education DOI: https://doi.org/10.1016/j.compedu.2016.04.004

[23] Gibb S 2014 Soft skills assessment: theory development and the research agenda International Journal of Lifelong Education

[24] Green F 2011 What is Skill? An Inter-Disciplinary Synthesis LLAKES Research Papers DOI: https:// doi.org/10.1053/j.gastro.2015.02.008.

[25] Gruman J A, Saks A M 2011 Performance management and employee engagement Human resource management review 21(2) 123-36

[26] Harzer C, Ruch W 2012 When the job is a calling: The role of applying one's signature strengths at work The Journal of Positive Psychology 7(5) 362-71

[27] Hill N 1937 Think and Grow Rich. US: The Ralston Society

[28] HM Staff 2010 HR: Marriott Employee Training and Development Program E-source: https://www. hotelmanagement.net/human-resources/hr-marriott-employee-training-and-developmentprogram Accessed 27.04.2020

[29] IBM Institute for Business Value Performance Data and Benchmarking 2019 Open Standards Talent 
Development Benchmark Study

[30] Iles P, Preece D, Chuai X 2010 Talent management as a management fashion in HRD: Towards a research agenda Human Resource Development International 13(2) 125-45

[31] JohansonM,GhiselliR,SheaL, RobertsC2013ChangingCompetenciesofHospitalityLeaders:A25-Year review Journal of Hospitality \& Tourism Education DOI: 23 43-7/10.1080/10963758.2011.10697012

[32] Kadarova J, Kočišová M 2016 Performance measures of industrial companies based on balanced scorecard 19 117-20 Research gate E-source: https://www.researchgate.net/figure/An-improvedmodel-of-business-performance-management-cycle-5_fig1_333134114 Accessed: 25 March 2020

[33] Keyton J 2008 Communication \& Organizational Culture: a Key to Understanding Work Experiences Communication Research Trends DOI: https://doi.org/1412980216, 9781412980210

[34] Khan T I, Jam F A, Akbar A, Khan M B, Hijazi S T 2011 Job involvement as predictor of employee commitment: Evidence from Pakistan International Journal of Business and Management 6(4) 252

[35] Kirkley J E, DuPaul W D 1989 Science, Commercial Practices, and the Determination of Fishery Regulations Journal of Shellfish Research 8 139-49

[36] Kirkley J, Squires D, Strand I E 1998 Characterizing Managerial Skill and Technical Efficiency in a Fishery Journal of Productivity Analysis

[37] Klingner D, Llorens J J, Nalbandian J 2015 Public personnel management Routledge

[38] Linley P A, Nielsen K M, Gillett R, Biswas-Diener R 2010 Using signature strengths in pursuit of goals: Effects on goal progress, need satisfaction, and well-being, and implications for coaching psychologists International Coaching Psychology Review 5(1) 6-15

[39] Livingstone D W 2018 The education-jobs gap: Underemployment or economic democracy? The Education-Jobs Gap: Underemployment or Economic Democracy? DOI: https://doi. org/10.4324/9780429496622

[40] Makransky G, Bonde M T, Wulff J S G, Wandall J, Hood M, Creed P A, Nørremølle A, et.al. 2016 Simulation based virtual learning environment in medical genetics counselling: an example of bridging the gap between theory and practice in medical education BMC Medical Education 16(1) 98 DOI: https://doi.org/10.1186/s12909-016-0620-6.

[41] Marriott B 2008 Cross Training at Marriott Hotels Means Better Service E-source: https://www.blogs. marriott.com/marriott-on-the-move/2008/03/cross-training-at-marriott-hotels-means-betterservice.html Accessed 27.04.2020

[42] Maxwell G A, MacLean S 2008 Talent management in hospitality and tourism in Scotland. Operational implications and strategic actions International Journal of Contemporary Hospitality Management 20(7)

[43] Mayo C, Thomas-Haysbert C 2005 Essential competencies needed by hospitality and tourism management graduates as determined by industry professionals and hospitality educators Consortium Journal of Hospitality and Tourism 9(2) 5-17

[44] Nema P, Nougriaya S 2015 Organisational Factors Impacting on Employee Retention: Literature Review International Journal of Engineering Technology \&Management Research 3(1) 139-46

[45] Nicole D, Vaughan C, Zabihullah S, Mei L 2016 Workplace training and generic and technical skill development in the Australian construction industry Journal of Management Development 35 486504 DOI: https://doi.org/10.1108/JMD-05-2015-0073

[46] Noe R A, Hollenbeck J R, Gerhart B, Wright P M 2015 Human resource management. Gaining a Competitive

[47] Nzozo J, Tsitsi C 2013 Managing Talent in the Tourism and Hospitality Sector: A Conceptual Viewpoint International Journal of Academic Research in Accounting, Finance and Management Sciences 3(2) $92-7$

[48] Oxenbridge S, Evesson J 2012 Young People Entering Work: A Review of the Research ACAS

[49] Paauwe J 2009 HRM and performance: Achievements, methodological issues and prospects Journal of Management Studies 46(1) 129-42

[50] Pink D H 2011 Drive: The surprising truth about what motivates us Penguin

[51] Rainsbury E, Hodges D, Burchell N, Lay M 2002 Ranking workplace competencies: Student and graduate perceptions Asia-Pacific Journal of Cooperative Education $\mathbf{3}$

[52] Rao S 2009 Talent management: an overview B.V.S.S. Assistant Professor, SRK Institute of Technology, Vijayawada. Ph: 9849976199

[53] Rathore S S, Rathore P 2015 Talent Management Practices in Luxury and Low Budget Hotels: Conceptual Viewpoint International Research Journal of Management Science \& Technology 6(7)

[54] Salas E, Shuffler M L, Thayer A L, Bedwell W L, Lazzara E H 2015 Understanding and Improving Teamwork in Organizations: A Scientifically Based Practical Guide Human Resource Management DOI: https://doi.org/10.1002/hrm.21628 
[55] Schon D A 1987 Teaching artistry through reflection in action. Educating the Reflective Practitioner

[56] Silzer R, Church Allan 2009 The Pearls and Perils of Identifying Potential Industrial and Organizational Psychology DOI: 2. 377-412. 10.1111/j.1754-9434.2009.01163.x

[57] Singh P J 2018 A Study of the Soft Skills that Contribute to the Success of Newly Graduated Business Students in the Workplace Mankato Cornerstone: A Collection of Scholarly and Creative Works for Minnesota State University, Mankato

[58] Stadtler M, Brand-Gruwel S 2011 Solving Information-based Problems: Searching, Selecting and Evaluating Information

[59] Tansley C 2011 What do we mean by the term "talent" in talent management? Industrial and Commercial Training DOI: 43. 266-274. 10.1108/00197851111145853

[60] Tice D M, Baumeister R F, Zhang L 2004 The role of emotion in self-regulation: Differing role of positive and negative emotions The regulation of emotion 213-26

[61] Tulgan B 2015 Bridging the Soft Skills Gap: How to Teach the Missing Basics to Today's Young Talent 1st Edition Publisher: Jossey-Bass

[62] Tyskbo D 2019 Competing institutional logics in talent management: talent identification at the HQ and a subsidiary The International Journal of Human Resource Management 1-35 DOI: 10.1080/09585192.2019.1579248

[63] Vaiman V, Scullion H, Collings D 2012 Talent management decision making Management Decision 50(5) 925-41

[64] Wellington J K 2005 The "Soft Skills" of success Vital Speeches of the Day 628-34

[65] Wheaton G 1990 Book Reviews: Power and Performance in Organizations by Iain L. Mangham (1986) Basil Blackwell Asia Pacific Journal of Human Resources 28(1) 94-5

[66] Wilks D, Hemsworth K 2011 Soft Skills Key Competencies in Hospitality Higher Education: Matching Demand and Supply Tourism \& Management Studies $\mathbf{7}$

[67] Wonderlic 2016 Hard Facts About Soft Skills: An Actionable Review of Employer Perspectives, Expectations and Recommendations E-source: http://docs.wixstatic.com/ugd/cceaf9 ec9ed750296142f18efdd49f4930f6d3.pdf Accessed 27.04.2020

[68] Wu M, Yang J, Liu L, Ye B 2016 An Investigation of Factors Influencing Nurses' Clinical, DecisionMaking Skills Western Journal of Nursing Research DOI: https://doi.org/10.1177/0193945916633458

[69] Zhang Y 2012 The impact of performance management system on employee Performance - Analysis with WERS 2004 (Master's thesis, University of Twente) 